\title{
Pemberdayaan Remaja Desa Wisata Bendosari Kecamatan Plantungan Kabupaten Kendal Melalui Pelatihan Pembuatan Papan Informasi Berbahasa Inggris dan Indonesia
}

\author{
Ngasbun Egar, Fitri Yulianti, Siti Musarokah, Donny Anhar Fahmi \\ Universitas PGRI Semarang \\ ngasbunegar@upgris.ac.id
}

Key word:

Tourism

village,

empowerment,

teenagers, information

boards

\section{Kata Kunci}

Desa wisata, pemberdayaan, remaja, papan informasi

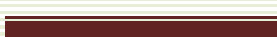

\section{Abstract}

Teenagers have an important role to develop the village into a tourist village. One of the roles is to develop existing facilities and infrastructure at tourist sites. Information boards are a very important part of tourism villages's management because it can be the information about tourist attractions, restrictions and warnings. Therefore, training and mentoring in making information boards in English and Indonesian need to be done in Bendosari Village, Plantungan District, Kendal Regency because of the limited number of information boards at tourist sites, especially in Jeglong Waterfall. The method used in the training is lecture, question and answer and practice. Participants in the training and mentoring activities for the making of this information board were the teenagers of Bendosari Village. The outcomes generated from these training activities are 1) teenagers 'understanding of the importance of information boards at tourist sites increases, 2) teenagers' understanding of the phrases used on information boards both in English and in Indonesian also increases, 3) models of information boards for tourist sites are created, and 4) nformation boards in English and Indonesian language for tourist sites are created as well.
Abstrak
Remaja memiliki peran yang penting untuk mengembangkan desa menjadi desa wisata. Salah satu perannya adalah mengembangkan sarana dan prasarana yang ada di lokasi wisata. Papan informasi merupakan bagian yang sangat penting dalam pengelolaan desa wisata sebagai informasi mengenai tempat wisata serta larangan- larangan dan peringatan. Oleh karena itu, pelatihan dan pendampingan pembuatan papan informasi berbahasa Inggris dan Indonesia perlu dilakukan di Desa Bendosari Kecamatan Plantungan Kabupaten Kendal karena terbatasnya jumlah papan informasi di lokasi wisata, khususnya di Curug Jeglong. Metode yang digunakan dalam pelatihan adalah ceramah, tanya jawab dan praktik. Peserta kegiatan pelatihan dan pendampingan pembuatan papan informasi ini adalah remaja Desa Bendosari. Luaran yang dihasilkan dari kegiatan pelatihan ini adalah 1) pemahaman remaja akan pentingnya papan informasi di lokasi wisata meningkat, 2) 
pemahaman remaja akan ungkapan-ungkapan yang digunakan pada papan informasi baik berbahasa Inggris maupun berbahasa Indonesia juga meningkat, 3) terciptanya model-model papan informasi untuk lokasi wisata, dan 4) terciptanya papan-papan informasi berbahasa Inggris dan Indonesia untuk lokasi wisata.

\section{PENDAHULUAN}

Sarana dan prasaran merupakan hal yang perlu menjadi perhatian bagi pengelola dalam pengembangan sector wisata. Fajriah dan Mussadun (2014) menyatakan bahwa untuk menunjang pariwisata, sarana dan prasarana memiliki peran yang penting. Lebih jauh mereka menyatakan bahwa selain sebagai alat untuk memenuhi kebutuhan wisata, sarana dan prasarana merupakan pengendali untuk memelihara keseimbangan lingkungan (Fajriah dan Mussadun, 2014). Agar daya tarik wisata (atraksi) berhasil memikat wisatawan, sebaiknya pembangunan atraksi atau daya tarik tersebut terpadu dengan sarana dan prasarana (Harun, 2008). Bahkan penelitian yang dilakukan oleh Gusneli (2016) menemukan bahwa fasilitas sangat mempengaruhi tingkat kepuasan pengunjung atau wisatawan. Lebih jauh Karyono (dalam Atmoko, 2014) menyatakan bahwa salah satu komponen yang harus dimiliki desa wisata adalah fasilitas pendukung. Oleh karena itu, sarana dan prasarana menjadi sangat penting dalam kegiatan kepariwisataan.

Namun sayangnya tak jarang tempat wisata alam mempunyai sarana dan prasarana yang kurang lengkap atau tidak memadai. Salah satunya adalah sedikitnya ketersediaan papan informasi yang berisi informasi, larangan, dan peringatan (notice, caution, warning). Tidak dapat dipungkiri bahwa keberadaan papan informasi sangatlah penting bagi para wisatawan. Terbatasnya ketersediaan papan informasi di tempat wisata disebabkan oleh beberapa hal seperti ketidaktahuan pengelola tempat wisata akan pentingnya keberadaan papan informasi di tempat wisata, kurangnya pengetahuan pengelola tempat wisata mengenai papan informasi itu sendiri, dan ketidaktahuan bagaimana cara membuat papan informasi tersebut.

Ketersediaan papan informasi merupakan hal yang sangat vital di tempat wisata. Menyediakan papan informasi di tempat wisata berarti juga melakukan pemenuhan hak untuk para wisatawan yang berkunjung. Papan informasi dapat berupa informasi mengenai tempat wisata tersebut, larangan-larangan yang tidak boleh dilakukan pada saat di tempat wisata, dan peringatan akan hal yang yang berpotensi berbahaya di tempat wisata. Maka dari itu, diperlukan suatu tindakan untuk menyediakan papan informasi di tempat wisata salah satunya adalah dengan 
melakukan pembuatan papan informasi untuk lokasi wisata.

Permasalahan tersebut ternyata juga dialami oleh Desa Bendosari Kecamatan Plantungan Kabupaten Kendal. Desa Bendosari memiliki potensi wisata yang sangat bagus, salah satunya adalah Curug Jeglong yang terletak di area hutan pinus dengan hawa yang sangat sejuk. Namun demikian, papan informasi yang merupakan salah satu sarana vital yang dimiliki oleh desa jumlahnya sangat terbatas. Pengelola sebenarnya memahami bahwa papan informasi sangat diperlukan di lokasi wisata. Namun, mereka mengalami kesulitan membuat papan informasi berbahasa Inggris maupun Indonesia karena jumlah personilnya yang terbatas. Padahal di kawasan wisata Curug Jeglong ini banyak sekali potensi remaja desa yang patut untuk diberdayakan. Waktu luang mereka juga lebih banyak dihabiskan dengan bersenda gurau bersama dengan teman sebayanya.

Oleh karena itu, pemberdayaan remaja melalui pelatihan pembuatan papan informasi menjadi solusi untuk mengatasi terbatasnya jumlah papan informasi di lokasi wisata Curug Jeglong. Sastrayuda (dalam Zakaria dan Suprihardjo, 2010) menyebutkan bahwa pelibatan masyarakat setempat menjadi salah satu usaha dalam mengembangkan desa wisata berkelanjutan. Sementara itu, Ramadhan dan Khadiyanto (2014) menyatakan, "Masyarakat sebagai salah satu pengelola dari desa wisata sangat menjadi faktor penentu dalam pengembangan pariwisata di Desa Wisata."

Pelatihan pembuatan papan informasi dibuat dalam dua bahasa yaitu bahasa Inggris dan bahasa Indonesia karena sangat mungkin para wisatawan tidak hanya turis lokal tetapi juga turis asing. Namun demikian, pemahaman dan kemampuan mereka akan konten dalam papan informasi yang digunakan di lokasi wisata sangat terbatas.

Artikel ini bertujuan untuk mendeskripsikan pelaksanaan kegiatan pemberdayaan remaja Desa Bendosari Kecamatan Plantungan Kabupaten Kendal melalui Pelatihan dan Pendampingan Pembuatan Papan Informasi Berbahasa Inggris dan Indonesia yang digunakan di lokasi wisata.

\section{METODE PEMECAHAN MASALAH}

Kegitaan pemberdayaan remaja Desa Bendosari ini merupakan salah satu kegiatan pemberdayaan yang dilaksanakan di Desa Bendosari Kecamatan Plantungan Kabupaten Kendal sebagai salah satu upaya untuk mewujudkan Desa Bendosari menjadi desa wisata berbasis EdugreenTourism. Kegiatan ini dilaksanakan pada 
tahun kedua Program Pemberdayaan Desa

Mitra (PPDM) yang difokuskan pada pemberdayaan Sumber Daya Manuasia Desa Bendosari.

$$
\text { Dalam melaksanakan }
$$

pemberdayaan kepada remaja Desa Bendosari yang tergabung dalam wadah Remaja Curug Jeglong Sejahtera, Tim PPDM menggunakan metode pelatihan dan pendampingan. Pelatihan dan pendampingan tersebut, yaitu pembuatan papan informasi berbahasa Inggris dan Indonesia yang digunakan di lokasi wisata. Pelatihan tersebut terbagi menjadi empat sesi (Penyampaian Materi 1, Penyampaian Materi 2, Praktik 1, dan Praktik 2) yang akan dijabarkan pada sub bab Hasil dan Pembahasan.

\section{HASIL}

Luaran dari kegiatan pengabdian adalah:

1. Terlaksananya Pelatihan Pembuatan Papan Informasi Berbahasa Inggris dan Indonesia;

2. Remaja warga desa wisata memahami dengan baik informasi wisata dalam bahasa Inggris dan Indonesia serta mampu untuk membuatnya dalam bentuk papan informasi;

3. Pemasangan papan informasi di lokasi wisata.

\section{PEMBAHASAN}

Pada tahun pertama pelaksanaan PPDM, pemberdayaan terhadap Mitra Paguyuban Remaja "Curug Jeglong Sejahtera" adalah Pelatihan dan Pendampingan Kepemanduwisataan atau Tour Guide dan Pelatihan Bahasa Inggris bagi pemandu wisata (Egar dkk., 2017). Sementara itu, pada tahun kedua, hasil yang yang sudah tercapai bagi mitra Paguyuban Remaja "Curug Jeglong Sejahtera" adalah Pelatihan Pembuatan Papan Informasi Berbahasa Inggris Indonesia. Pelatihan ini dipandang perlu dilakukan di awal pelaksanaan Program PPDM tahun ke-2 karena papan infromasi yang ada di lokasi wisata Curug Jeglong jumlahnya masih sangat terbatas. Metode yang digunakan dalam kegiatan pelatihan ini adalah ceramah, diskusi, tanya jawab dan praktik. Pelatihan ini dilaksanakan dalam empat sesi, yaitu penyampaian Materi 1, penyampaian Materi 2, Praktik 1, dan Praktik 2 yang akan dijabarkan sebagi berikut.

Sesi pertama diisi dengan materi 1 "Pentingnya Papan Informasi di Lokasi Wisata". Hal ini diberikan agar remaja memahami bahwa papan informasi yang tersedia di lokasi wisata sangat bermanfaat bagi para pengunjung. Penyampaian Materi ini juga dimaksudkan agar remaja memahami bahwa dengan adanya papan 
informasi wahana atau lokasi tertentu dapat dijangkau oleh pengunjung dengan lebih mudah. Hal ini juga dilakukan agar pemahaman remaja akan tempat-tempat yang membahayakan pengunjung juga perlu menjadi perhatian dalam pembuatan papan informasi. Metode yang digunakan dalam sesi ini adalah ceramah dan tanya jawab. Pada saat narasumber menyampaikan materi, peserta dalam hal ini remaja juga bisa langsung bertanya tentang materi. Luaran yang dihasilkan dari sesi ini adalah remaja memahami pentingnya papan informasi bagi pengunjung di lokasi wisata. Mereka juga memahami bahwa papan informasi juga sangat vital bagi wisatawan atau pengunjung untuk mencari wahana yang tersedia di lokasi wisata mengetahui tempat-tempat yang sebaiknya pengunjung perlu berhati-hati.

Pada sesi kedua Tim pengabdian memberikan materi tentang UngkapanUngkapan Bahasa Inggris dan Indonesia yang digunakan di berbagai papan informasi yang ada di tempat wisata kepada peserta pelatihan. Ungkapan-ungkapan tersebut meliputi Informasi (Pemberitahuan), Peringatan, dan Larangan. Ekspresi-ekspresi tersebut misalnya "No Littering", "Slippery When Wet", "Ranting Pohon Besar, Hati-Hati", "Perhatikan Bebatuan di Jalan", dan lain- lain. Tujuan dari sesi kedua ini adalah untuk memberikan pengetahuan kepada remaja akan ungkapan-ungkapan yang benar yang digunakan dalam papan informasi yang ada di lokasi wisata. Metode yang digunakan pada sesi kedua, yaitu ceramah dan tanya jawab. Sebelumnya remaja hanya mengetahui beberapa ungkapan saja yang berbahasa Indonesia, dan mereka tidak memahami ungkapan yang digunakan di papan informasi berbahasa Inggris. Namun, setelah diberikan materi, pemahaman remaja akan ungkapan-ungkapan Bahasa Inggris dan Indonesia yang digunakan dalam papan informasi baik berbahasa Inggris maupun Indonesia di lokasi wisata meningkat. Peningkatan pemahaman remaja ini diukur secara kualitatif yang dilakukan dengan memberikan kesempatan bagi remaja setempat untuk menjelaskan ulang ungkapan-ungkapan Bahasa Inggris dan Bahasa Indonesia.

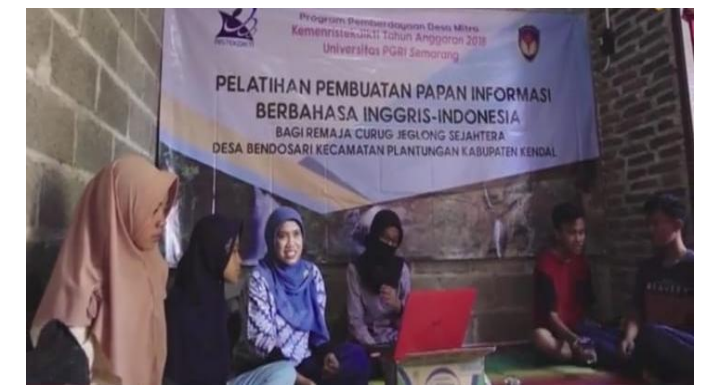

Gb 1. Penyampaian Materi tentang Pentingnya Papan Informasi 


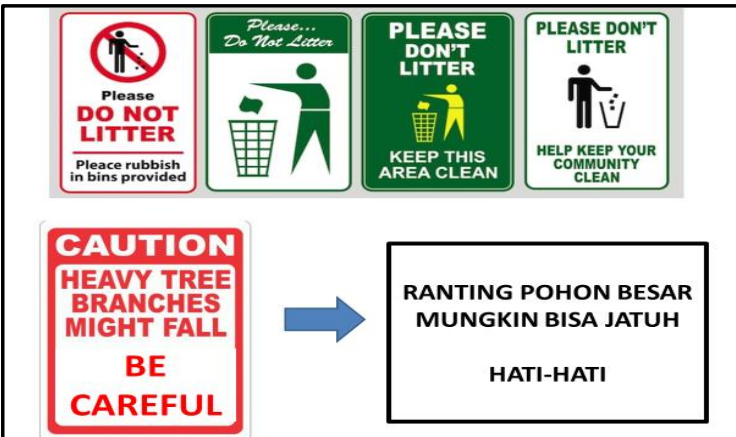

Gb 2. Contoh Papan Informasi

Sesi berikutnya adalah praktik atas materi pertama. Remaja mempraktikkan membuat informasi menggunakan ekspresi yang telah mereka pahami secara individu. Praktik pertama ini dilakukan dengan membuat atau menggambar informasi meggunakan kertas gambar. Luaran yang didapat dari kegiatan ini adalah selain mereka semakin memahami ekspresiekspresi yang digunakan di papan informasi, mereka juga masing-masing berkreasi menghasilkan berbagai model papan informasi.

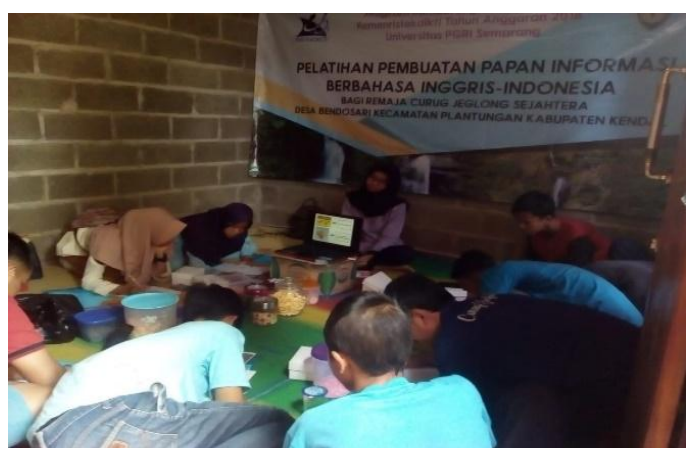

Gb 3. Praktik Menggambar Papan Informasi

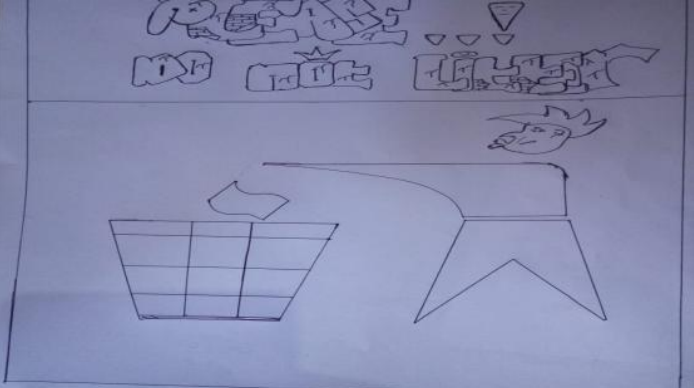

Gb 4. Hasil Praktik

Setelah praktik menggambar papan informasi di kertas gambar secara individu, kemudian remaja mempraktikkan secara langsung membuat papan informasi menggunakan papan atau kayu beserta cat yang sudah disediakan. Mereka membuat papan informasi secara berkelompok. Dalam kegiatan praktik 2 ini terbentuk empat kelompok dan masing-masing kelompok membuat papan informasi secara berbeda. Luaran dari kegiatan ini adalah terciptanya papan-papan informasi berbahasa Inggris dan Indonesia. Berikut foto-foto kegiatan Pelatihan Pembuatan Papan Informasi Berbahasa InggrisIndonesia.

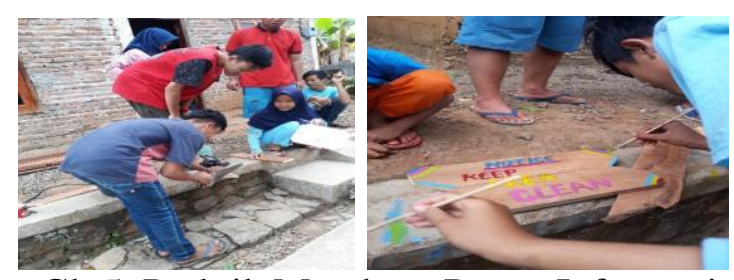

Gb 5. Praktik Membuat Papan Informasi 


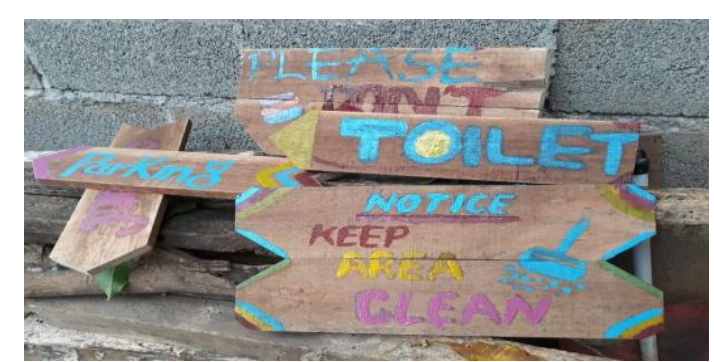

Gb 6. Hasil Praktik

Kegiatan selanjutnya setelah pelatihan pembuatan papan informasi berbahasa Inggris dan Indonesia adalah pendampingan. Pendampingan secara berkala dilakukan agar hasil dari pelatihan dapat secara terus menerus diterapkan oleh remaja. Pembuatan papan informasi selanjutnya dilakukan sesuai dengan kebutuhan di lokasi wisata.

\section{SIMPULAN}

Program Pemberdayaan Desa Mitra (PPDM) dengan fokus remaja Desa Bendosari Kecamatan Plantungan secara keseluruhan dapat berjalan dengan baik dan lancar. Luaran yang dihasilkan dari kegiatan pelatihan dan pendampingan pembuatan papan informasi berbahasa Inggris dan Indonesia untuk lokasi wisata, yaitu 1) pemahaman remaja akan pentingnya papan informasi di lokasi wisata meningkat, 2) pemahaman remaja akan ungkapan-ungkapan yang digunakan pada papan informasi baik berbahasa Inggris maupun berbahasa Indonesia juga meningkat, 3) terciptanya model-model papan informasi untuk lokasi wisata, dan 4) terciptanya papan-papan informasi berbahasa Inggris dan Indonesia untuk lokasi wisata.

\section{SARAN}

Berdasarkan hasil dari kegiatan pemberdayaan remaja Curug Jeglong Sejahtera Desa Bendosari Kecamatan Plantungan, beberapa saran dapat diberikan sebagai berikut:

1. Remaja Desa Bendosari yang terlibat dalam kegiatan pelatihan seharusnya memotivasi dan mengajak remaja yang lain yang masih acuh untuk turut serta menjadi motor penggerak pengembangan Desa Bendosari menjadi Desa Wisata Berbasis Edugreen-Tourism karena di tangan merekalah berkembang atau tidaknya Desa Bendosari menjadi desa wisata;

2. Remaja Desa Bendosari seharusnya terus meningkatkan kreatifitasnya dalam membuat papan informasi, sehingga papan informasi tidak hanya berfungsi sebagai sumber informasi di lokasi wisata, namun juga memberikan arahan kepada wisatawan bahwa lokasi tertentu perlu menjadi perhatian wisatawan karena berbahaya atau perlu kehati-hatian ketika berada di lokasi wisata tersebut; 
3. Perlu pendampingan berkala baik dilakukan oleh Tim pengabdian masyarakat maupun pihak pengelola desa wisata agar kegiatan ini dapat terus berjalan.

\section{UCAPAN TERIMA KASIH}

Terima kasih yang setinggi-tingginya kami sampaikan kepada Kemenristekdikti yang telah membiayai secara penuh program PPDM pada tahun kedua ini. Terima kasih juga kami sampaikan kepada Rektor Universitas PGRI Semarang dan LPPM Universitas PGRI Semarang yang telah sepenuh hati memberikan motivasi, mengarahkan, dan mendukung secara penuh kegiatan PPDM ini.

\section{DAFTAR PUSTAKA}

Atmoko, T. P. H. (2014). Strategi Pengembangan Potensi Desa Wisata Brajan Kabupaten Sleman. Wahana Informasi Pariwisata: MEDIA WISATA, 12(2), 146-154.

Egar, N., Fahmi, D. A., Yulianti, F., \& Musarokah, S. (2017). Pemberdayaan Remaja Desa Wisata Bendosari Kecamatan Plantungan Kabupaten Kendal Melalui Pelatihan Kepemanduwisataan. Journal of Dedicators Community, 1(2).
Fajriah, S. D., \& Mussadun, M. (2014). Pengembangan Sarana dan Prasarana untuk Mendukung Pariwisata Pantai yang Berkelanjutan (Studi Kasus: Kawasan Pesisir Pantai Wonokerto Kabupaten Pekalongan). Jurnal Pembangunan Wilayah \& Kota, 10(2), 218-233.

Gusneli, G., Silfeni, S., \& Kasmita, K. (2016). 1 Pengaruh Fasilitas Wisata terhadap Kepuasan Pengunjung ke Objek Wisata Air Terjun Bayang Sani Kabupaten Pesisir Selatan. EJournal Home Economic and Tourism, 11(1).

Harun, Rochajat. 2008. Mengembangkan Objek Wisata Alam. Diakses di http://www.bbpp-

lembang.info/index.php/arsip/artikel/ artikel-umum/145-mengembangkanobjek-wisata-alam pada 21 Oktober 2018.

Ramadhan, F., \& Khadiyanto, P. (2014). Partisipasi Masyarakat dalam Mendukung Kegiatan Pariwisata di Desa Wisata Bejiharjo, Gunungkidul, YOGYAKARTA. Teknik PWK (Perencanaan Wilayah Kota),3(4), 949-963. 
Zakaria, F., \& Suprihardjo, R. (2014).

Konsep Pengembangan Kawasan

Desa Wisata di Desa Bandungan

Kecamatan Pakong Kabupaten

Pamekasan. Jurnal Teknik ITS, 3(2),

C245-C249. 